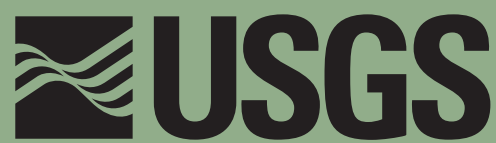

science for a changing world

Prepared in cooperation with the Colorado Department of Transportation

\title{
Real-Time Streambed Scour Monitoring at Two Bridges over the Gunnison River in Western Colorado, 2016-17
}

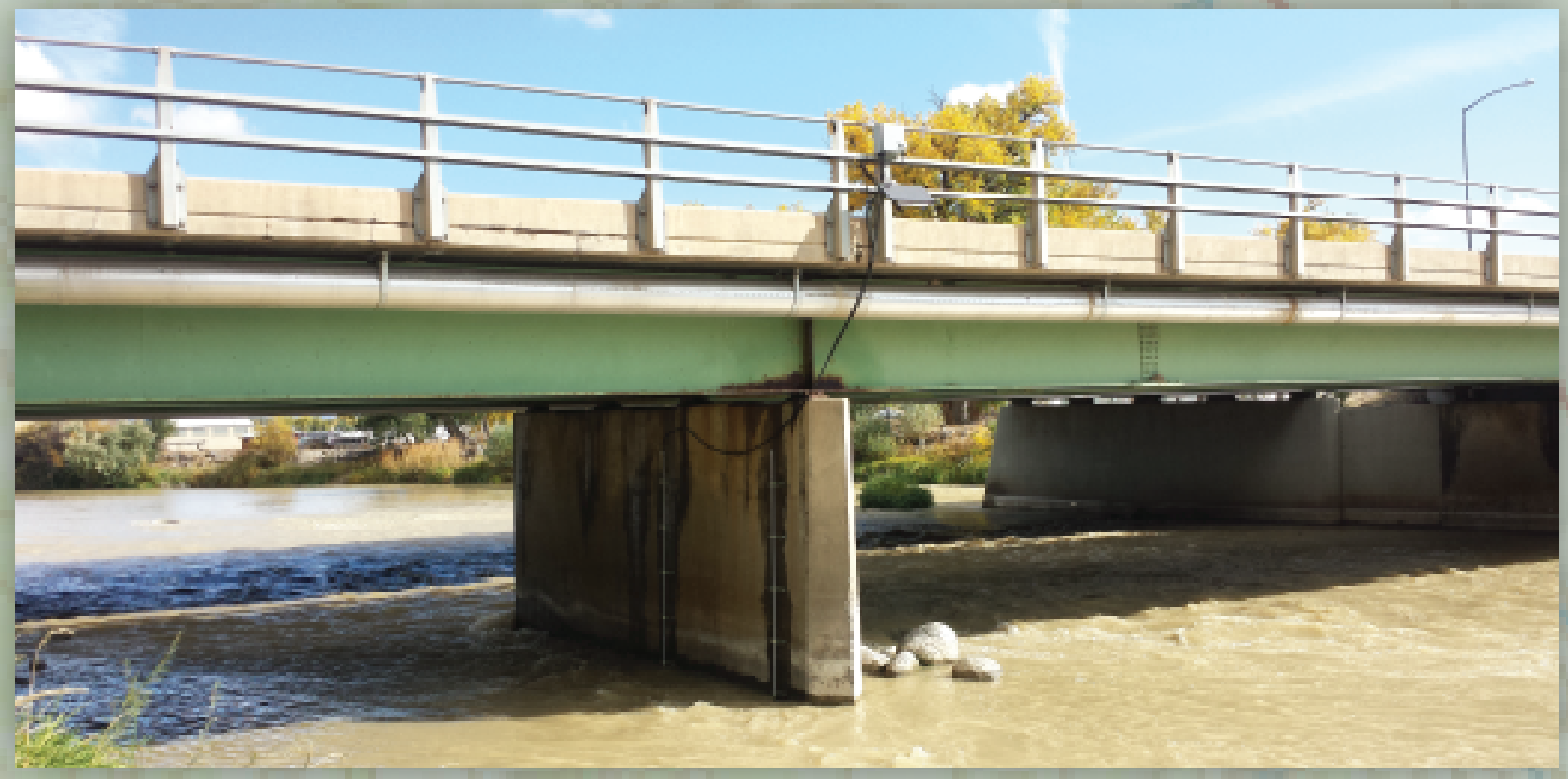

Scientific Investigations Report 2018-5123 
Cover photograph. Sensor installation on bridge I-04-K, from the north side of pier 3, looking upstream, western Colorado. Photograph by the U.S. Geological Survey. 


\section{Real-Time Streambed Scour Monitoring at Two Bridges over the Gunnison River in Western Colorado, 2016-17}

By Mark F. Henneberg

Prepared in cooperation with the Colorado Department of Transportation

Scientific Investigations Report 2018-5123 


\section{U.S. Department of the Interior \\ RYAN K. ZINKE, Secretary}

\section{U.S. Geological Survey James F. Reilly II, Director}

\section{U.S. Geological Survey, Reston, Virginia: 2018}

For more information on the USGS - the Federal source for science about the Earth, its natural and living resources, natural hazards, and the environment-visit https://www.usgs.gov or call 1-888-ASK-USGS.

For an overview of USGS information products, including maps, imagery, and publications, visit https://store.usgs.gov.

Any use of trade, firm, or product names is for descriptive purposes only and does not imply endorsement by the U.S. Government.

Although this information product, for the most part, is in the public domain, it also may contain copyrighted materials as noted in the text. Permission to reproduce copyrighted items must be secured from the copyright owner.

Suggested citation:

Henneberg, M.F., 2018, Real-time streambed scour monitoring at two bridges over the Gunnison River in western Colorado, 2016-17: U.S. Geological Survey Scientific Investigation Report 2018-5123, 15 p., https://doi.org/10.3133/sir20185123.

ISSN 2328-0328 (online) 


\section{Contents}

Abstract

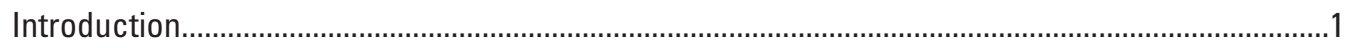

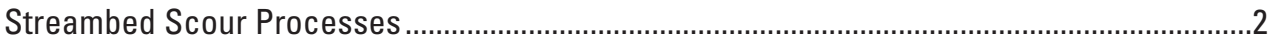

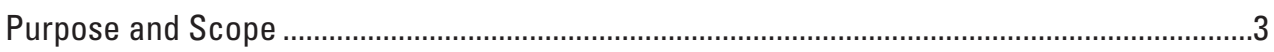

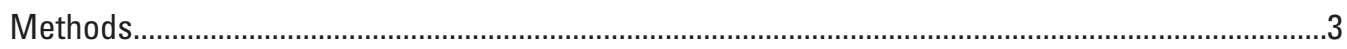

Real-Time Instrumentation and Data Collection.....................................................................

Description of Newly Developed Technology...................................................................

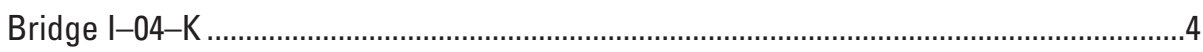

Bridge I-03-A ...........................................................................................................

Cross-Section Survey Techniques and Statistical Analyses.....................................................

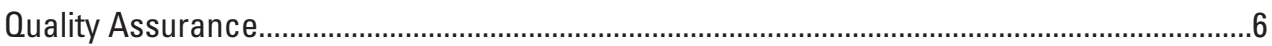

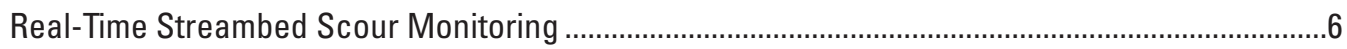

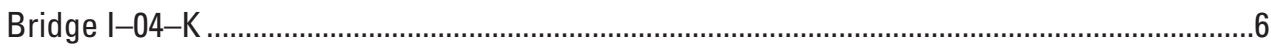

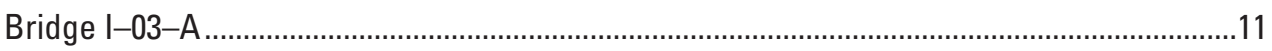

Advancement of Monitoring Technology and Implications for Future Monitoring.................13

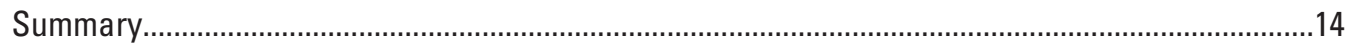

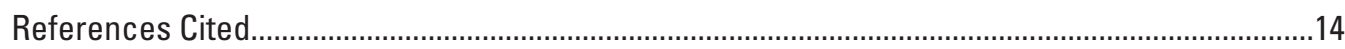

\section{Figures}

1. Map showing locations selected for streambed-scour monitoring in western Colorado at U.S. Highway 50 eastbound over the Gunnison River at milepost 70.0 (bridge I-04-K) and Colorado Highway 141 bridge over the Gunnison River at milepost 153.7 (bridge I-03-A).

2. Photograph showing an example of a National Marine Electronics Association 0183 to Serial Digital Interface at 1,200-Baud protocol converter dialog and equipment; photograph by the U.S. Geological Survey.

3. Photograph showing the sensor installation on bridge $\mathrm{I}-04-\mathrm{K}$, from the north side of pier 3, looking upstream, western Colorado; photograph by the U.S. Geological Survey ...

4. Photograph showing the sensor installation on bridge $\mathrm{I}-03-\mathrm{A}$, from the south side of pier 4, looking downstream, western Colorado; photograph by the U.S. Geological Survey.

5. Cross section showing the streambed elevation surveys of the Gunnison River at bridge $\mathrm{I}-04-\mathrm{K}$ with the location of the bridge structure, western Colorado, 2016 and 2017

6. Cross section showing the streambed elevation surveys of the Gunnison River at bridge I-03-A with the location of the bridge structure, western Colorado, 2016 and 2017.

7. Graph showing streambed elevation at bridge $\mathbf{I}-04-\mathrm{K}$ and streamflow from U.S. Geological Survey streamflow-gaging station 09144250 during snowmelt runoff in 2017, western Colorado

8. Underwater photograph showing undermining of bridge I-03-A at pier 4, western Colorado, February 2016; photograph by the U.S. Geological Survey. 


\section{Tables}

1. Streambed-elevation data and statistical test results of comparisons of survey data at bridge I-04-K, western Colorado, 2016-17.

2. Streambed-elevation data and statistical test results of comparisons of survey data at bridge I-03-A, western Colorado, 2016-17.

\section{Conversion Factors}

U.S. customary units to International System of Units

\begin{tabular}{lll}
\hline \multicolumn{1}{c}{ Multiply } & By & \multicolumn{1}{c}{ To obtain } \\
\hline foot $(\mathrm{ft})$ & Length & \\
mile $(\mathrm{mi})$ & 0.3048 & meter $(\mathrm{m})$ \\
\hline & 1.609 & kilometer $(\mathrm{km})$ \\
\hline foot per second $(\mathrm{ft} / \mathrm{s})$ & Flow rate & \\
cubic foot per second $\left(\mathrm{ft}^{3} / \mathrm{s}\right)$ & 0.3048 & meter per second $(\mathrm{m} / \mathrm{s})$ \\
\hline
\end{tabular}

\section{Datum}

Vertical coordinate information is referenced to the North American Vertical Datum of 1988 (NAVD 88).

Horizontal coordinate information is referenced to the North American Datum of 1983 (NAD 83).

\section{Supplemental Information}

Sediment sizes are given in millimeters ( $\mathrm{mm})$.

Data rates are given in hertz $(\mathrm{Hz})$. 


\section{Abbreviations}

CDOT Colorado Department of Transportation

DCP data collection platform

NMEA National Marine Electronics Association

NWIS National Water Information System

$p$-value significance level

RTK-GNSS real-time kinematic Global Navigation Satellite System

SDI-12 Serial Digital Interface at 1,200 Baud

USGS U.S. Geological Survey 



\title{
Real-Time Streambed Scour Monitoring at Two Bridges over the Gunnison River in Western Colorado, 2016-17
}

\author{
By Mark F. Henneberg
}

\section{Abstract}

The Colorado Department of Transportation maintains roadways crossing over large streams and rivers where sediment transport and channel alignment changes can affect the structural stability of bridges. Structural stability during and immediately after peak streamflow can be assessed by measuring streambed scour; however, placing personnel or boats in the water during high-streamflow events using traditional methods can be difficult, hazardous, and time consuming. To address this need, the U.S. Geological Survey, in cooperation with Colorado Department of Transportation, installed instrumentation at two bridges in western Colorado to measure streambed elevations in real-time during snowmelt-runoff periods (May through June) in 2016 and 2017. The bridges include U.S. Highway 50 eastbound over the Gunnison River at milepost 70.0 (bridge I-04-K) and Colorado Highway 141 over the Gunnison River at milepost 153.7 (bridge I-03-A).

Bridge I-04-K was outfitted with two echosounders, each mounted on the north side of pier 3. Data collected during the 2016 snowmelt runoff did not indicate scour had occurred. Data collected during 2017 snowmelt runoff indicated minor scour and fill occurred under the downstream echosounder.

Bridge I-03-A was outfitted with two echosounders, each mounted on opposite sides of pier 4 , at the transition of the upstream nose to the straight section of the pier wall. Data recorded during 2016 did not indicate any scour under the echosounders. Debris accumulation around the nose of the pier and under the echosounders resulted in inconsistent streambed elevation data. Data recorded during 2017 did not indicate any scour under the echosounders. Probing of the pier wall and streambed interface and underwater photographs obtained in 2016 revealed undermining along the length of the pier wall. The undermining extended side-to-side to a depth of about 2 feet. Underwater photographs were obtained again in 2017; no changes from the previous year were observed.

Cross-section surveys were completed at each bridge to measure and document changes in channel geometry during the study. Surveys were performed in spring 2016 before snowmelt runoff, spring 2017 before snowmelt runoff, and fall 2017. Streambed elevations from cross-section surveys at both bridges were evaluated using two-tailed, paired t-tests and Wilcoxon rank sum tests to identify significant changes between the surveys. Both tests indicated significant changes in mean streambed elevations for the cross-sections and around the monitored piers at bridges $\mathrm{I}-04-\mathrm{K}$ and $\mathrm{I}-03-\mathrm{A}$ during the 2-year study.

\section{Introduction}

The Colorado Department of Transportation (CDOT) maintains roadways crossing over large streams and rivers where sediment transport and channel alignment changes can affect the structural stability of bridges. Structural stability during and immediately after peak streamflow can be assessed by measuring streambed scour; however, placing personnel or boats in the water during high-streamflow events using traditional methods can be difficult, hazardous, and time consuming.

Streambed scour, the mobilization and degradation of bed material, is the leading cause of bridge failure in the United States (Murillo, 1987; Butch, 1991). Recent flooding and associated streambed scour from the September 2013 flood in eastern Colorado highlights the importance of real-time monitoring. The flooding caused major damage and road closures at structures adjacent to or spanning streams and rivers limiting access to entire municipalities. About 486 miles of State roadways were affected; 39 roadways were temporarily closed; and 120 State bridges were damaged (CDOT, 2015).

Monitoring streambed conditions during floods is important for public safety but can put monitoring staff at risk to extreme streamflow hazards. To address this need, the U.S. Geological Survey (USGS), in cooperation with CDOT, began a pilot study and installed instrumentation at two bridges in western Colorado to measure streambed elevations in real-time during snowmelt-runoff periods (May through June) in 2016 and 2017. Bridge selection and the timing of the monitoring was a joint effort between CDOT and the USGS and included U.S. Highway 50 eastbound over the Gunnison River at milepost 70.0 (bridge I-04-K) (fig. 1) and Colorado Highway 141 over the Gunnison River at milepost 153.7 (bridge I-03-A) when peak streamflow is expected from snowmelt runoff in the area. These installations were co-located with USGS streamflow-gaging stations 09144250 (Gunnison River at Delta, Colorado) and 09152500 (Gunnison River near Grand Junction, Colo.), respectively.

Both of the selected bridges are currently (2017) listed on CDOT's scour critical inventory (CDOT, 2012a; CDOT, 2012b). 


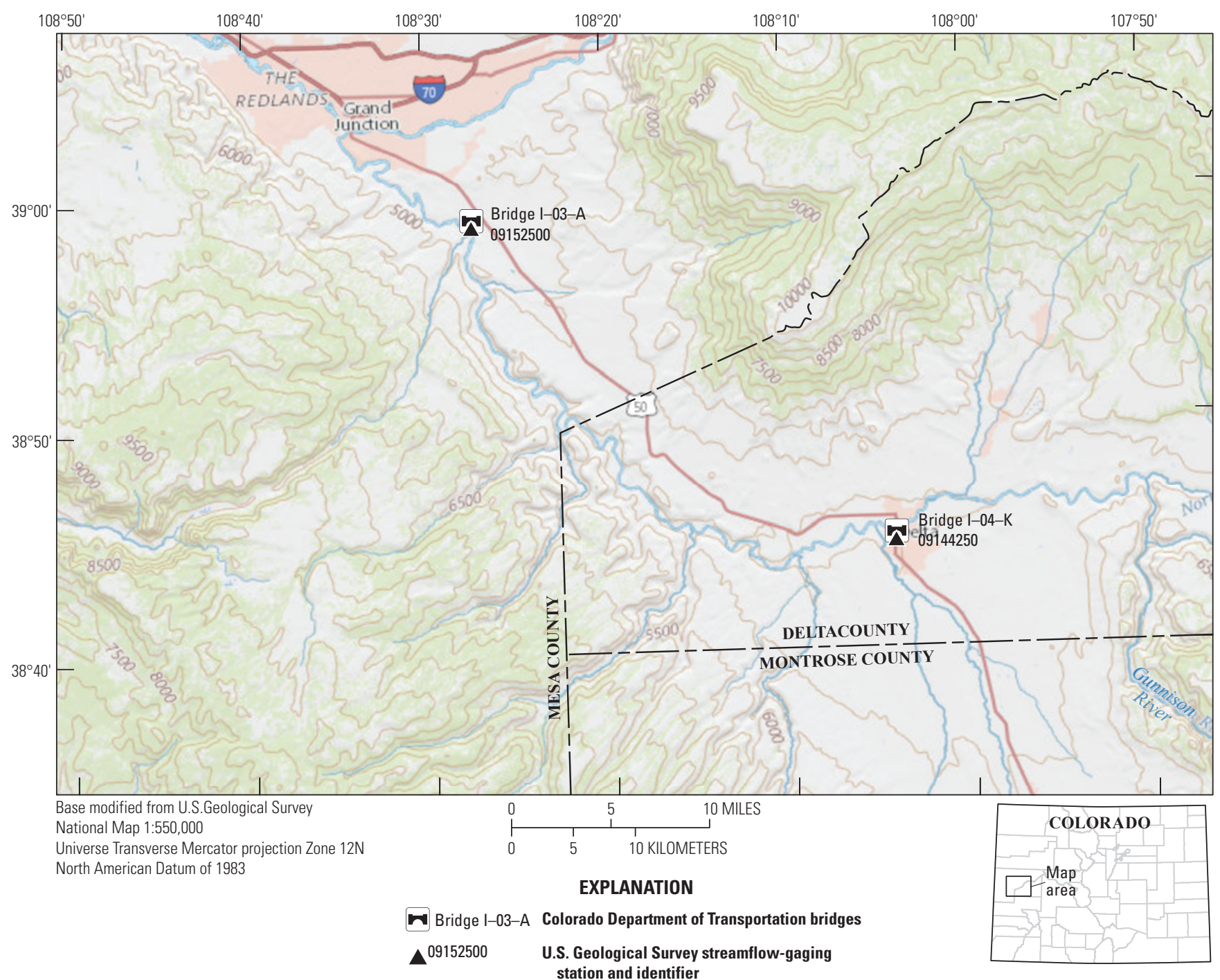

Figure 1. Locations selected for streambed-scour monitoring in western Colorado at U.S. Highway 50 eastbound over the Gunnison River at milepost 70.0 (bridge I-04-K) and Colorado Highway 141 bridge over the Gunnison River at milepost 153.7 (bridge $\mathrm{I}-03-\mathrm{A})$.

Bridges I-04-K and I-03-A are on the Gunnison River in western Colorado. The Gunnison River Basin has a drainage area of almost 8,000 square miles $\left(\mathrm{mi}^{2}\right)$ at its confluence with the Colorado River at Grand Junction, Colo. Most of the mainstem runoff is generated by spring snowmelt runoff; however, upstream reservoirs have altered the timing and magnitude of Gunnison River flood peaks since 1966. Flood magnitudes of given recurrence intervals have decreased substantially since 1966 (Elliot and Hammack, 1999).

\section{Streambed Scour Processes}

Streambed scour at a bridge is generally divided into three processes. The first process includes aggradation and degradation, which are long-term changes in streambed elevation because of natural or human-induced causes and can affect the reach of the river near the bridge. The second process is contraction scour, the removal of material from the bed and banks across all or most of the channel width because of a reduction of the cross-sectional flow area. The third process is local scour, the removal of bed material from around piers, abutments, spurs, and embankments. Local scour is caused by the acceleration of streamflow and by vortices resulting from streamflow around an obstruction (Mueller and Wagner, 2005).

Monitoring real-time streambed elevations at specific locations in conjunction with periodic cross-section surveys may help identify the type of scour at a bridge. Comparisons can be made between changes in streambed elevations observed at discrete locations and more generalized changes measured in cross-section surveys. 


\section{Purpose and Scope}

The purpose of this report is to evaluate a method using newly developed technology to monitor streambed scour around bridges. Instrumentation was installed at two bridges in western Colorado to measure streambed elevations in real-time during snowmelt-runoff periods (May-June) in 2016 and 2017. Cross-section surveys also were completed at each bridge to measure and document changes in channel geometry during the study. Streambed elevations from the cross-section surveys were analyzed to identify when changes may have occurred using two-tailed, paired t-tests and Wilcoxon rank sum tests.

This report presents the following for two bridges, $\mathrm{I}-04-\mathrm{K}$ and $\mathrm{I}-03-\mathrm{A}$, over the Gunnison River in western Colorado (fig. 1): real-time instrumentation and data collection, cross-section surveys, statistical analyses, discussion of observed conditions during real-time streambed scour monitoring, and implications for future monitoring. Stationing and elevation data are presented in a USGS data release (Henneberg, 2018).

\section{Methods}

This section presents the methods implemented for realtime instrumentation and data collection, cross-section surveys, statistical analyses, and quality assurance of elevation data.

\section{Real-Time Instrumentation and Data Collection}

Acoustic echosounders were installed on the selected bridges to measure streambed elevations adjacent to supporting piers in real-time and deliver the data through available USGS web-based services. The data from these installations were logged and transmitted by data collection platforms (DCPs), relayed through the Geostationary Operational Environmental Satellite network to the National Water Information System (NWIS) database website for data storage and dissemination (https://doi.org/10.5066/F7P55KJN; USGS, 2018a). Streambed elevations were recorded every 15 minutes and telemetered hourly during the snowmelt-runoff period (May through June). The streambed elevation data hosted on the NWIS database website were available to the USGS WaterAlert service, which any end-user can access to design their own alarm notification based on user-specific thresholds (https://maps.waterdata.usgs.gov/mapper/wateralert/).

\section{Description of Newly Developed Technology}

The USGS has engaged in previous studies using piermounted echosounders to continuously monitor streambed scour conditions in other States in cooperation with other department of transportation offices (Walker and Hughes, 2005; Conaway and Brabets, 2011; Conaway and Schauer, 2012). Many of these studies used acoustic echosounders originally developed for marine applications. These sensors measure distance from the sensor to the streambed and typically report data using the National Marine Electronics Association 0183 (NMEA 0183) Interface Standard.

The NMEA 0183 Interface Standard defines electrical signal requirements, data transmission protocol and time, and specific sentence formats for a 4,800-baud serial data bus (NMEA, 2017). Although standardized NMEA 0183 sensors interconnect with a wide variety of marine instruments, the 4,800-baud serial data generated by acoustic echosounders limit the type of DCPs that can receive, interpret, and telemeter the measurement values. The DCP must be able to receive a serial data string and may require custom programming to parse and store values from the data sentences. Additionally, most DCPs have a finite number of serial data ports, restricting the number of acoustic echosounders that can be connected to a DCP to the number of serial ports available.

Sensors and DCPs used at most USGS streamflow-gaging stations communicate using the Serial Digital Interface at 1,200-Baud (SDI-12) protocol, developed specifically for hydrologic instrumentation. The SDI-12 protocol was created in 1988 by a group of private firms and the USGS Hydrologic Instrumentation Facility. The SDI-12 protocol is a standard to interface battery-powered data recorders (for example, DCPs) with microprocessor-based sensors designed for environmental data acquisition. A SDI-12 sensor typically takes a measurement, facilitates computations based on the raw sensor reading, and outputs the measured data in engineering units. The sensor's microprocessor makes the computations, converts sensor readings into the appropriate units, and uses the SDI-12 protocol to transfer data to the DCP (SDI-12 Support Group, 2018). Additionally, SDI-12 is a multidrop interface and permits each sensor to be uniquely addressed, which allows multiple sensors to be connected to one DCP (SDI-12 Support Group, 2018).

To interface acoustic echosounders used for marine applications with DCPs in widespread use by the USGS, a protocol converter was developed by Pacific Data Systems, Proprietary Limited of Australia, and the USGS (Pacific Data Systems, 2017). The echosounders used for the study produce NMEA 0183 data sentences at 1 hertz. The protocol converter receives the serial data sentence from the echosounder, parses the sentence for the pertinent data values, stores those values in a register, and makes the registered values available using the SDI-12 protocol (fig. 2). The values in the register update at 1 hertz as new data are acquired from the echosounder. Each protocol converter is addressable as an individual SDI-12 sensor, so multiple echosounders can be connected to any SDI-12-compliant DCP. The converter and the echosounder are powered by the SDI-12 power supply from the DCP. Error checking was incorporated in the protocol conversion, such that any data missing from the echosounder result in " -1 " values in the SDI-12 data register. Connecting an echosounder to any SDI-12-compliant DCP with the protocol converter requires no custom programming because the protocol converter responds to standard SDI-12 commands. 

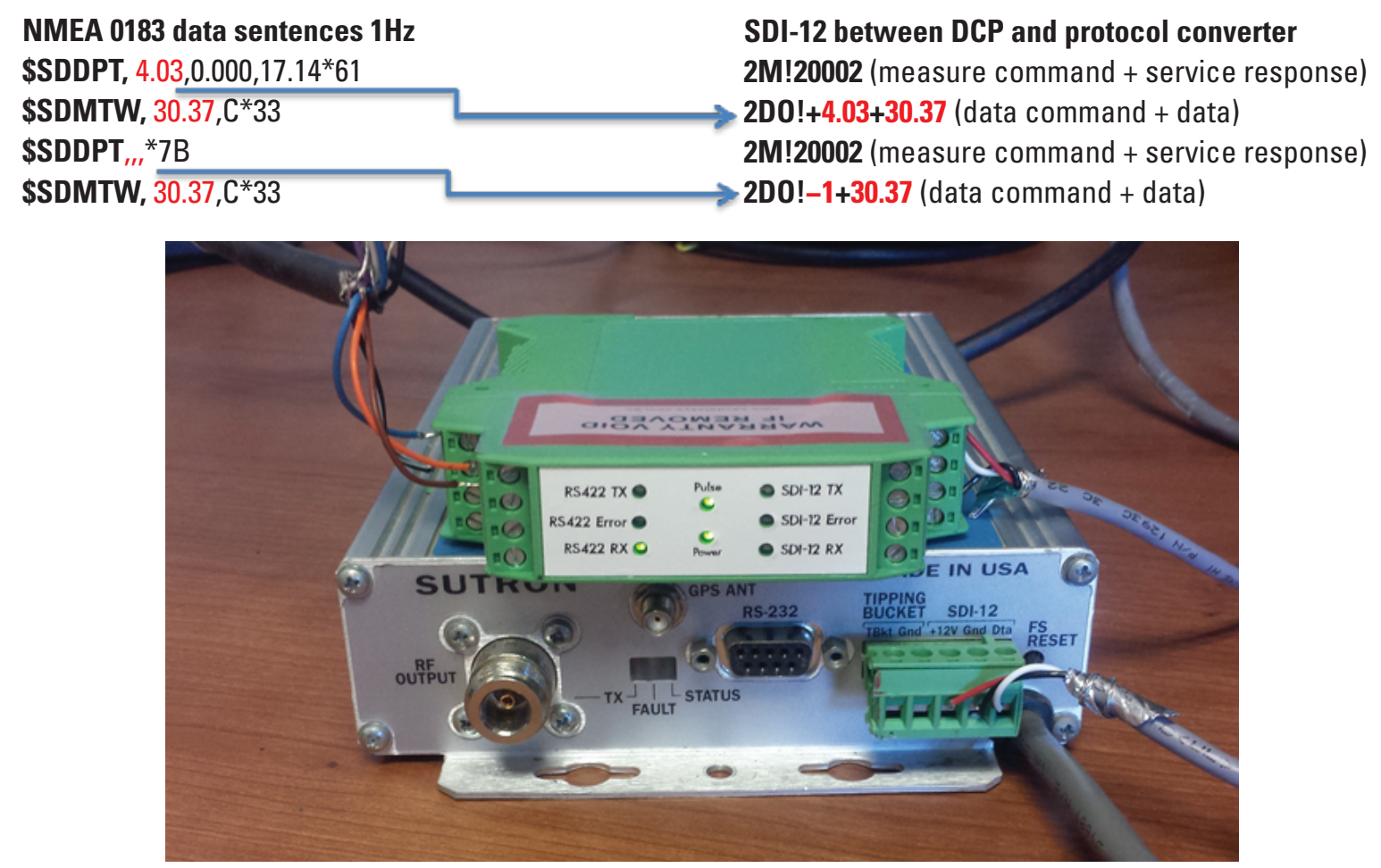

EXPLANATION

NMEA 0183 National Marine Electronics Association 0183 Protocol

SDI-12 Serial Digital Interface at 1,200 Baud

DCP data collection platform

\$SDDPT depth below transducer sentence

\$SDMTW measured water temperature sentence

2M! SDI-12 measure command for address 2

2D0! SDI-12 data command for address 2

$\mathrm{Hz}$ hertz

Figure 2. Example of a National Marine Electronics Association 0183 to Serial Digital Interface at 1,200-Baud protocol converter dialog and equipment; photograph by the U.S. Geological Survey.

\section{Bridge I-04-K}

Bridge I-04-K was configured with two Airmar EchoRange $^{\mathrm{TM}}$ Smart ${ }^{\mathrm{TM}}$ Sensor echosounders (Airmar Technology Corporation, 2017), each mounted on the north side of pier 3 (fig. 3). Each sensor was connected to a protocol converter. The protocol converters were connected to a SDI-12 data radio mounted in an enclosure on the bridge railing. A second data radio was installed at the existing, streamflow-gaging station enclosure, about 1,500 feet (ft) downstream, and connected to a DCP in the enclosure for data logging and transmission. Relaying data using SDI-12 data radio minimized the installation footprint on the bridge and reduced the amount of time field staff were required to work on the roadway. The upstream and downstream echosounders were mounted at elevations of 4,924.73 and 4,924.76 ft, respectively, above the North American Vertical Datum of 1988 (NAVD 88). Because of water depths and velocities, most of the instrumentation was installed by motor boat; however, probing and inspecting the streambed and pier wall interface was possible while wading at this site during the lowest streamflow. Each echosounder has a beam width of 9 degrees, which results in an acoustic footprint of about $0.5 \mathrm{ft}$ in diameter at the base of the pier assuming the distance to streambed is about $4 \mathrm{ft}$. The diameter of the acoustic footprint will change with measured distance because streambed elevations vary over time. Incoming data were hosted on the NWIS website for USGS streamflow-gaging station 09144250 (USGS, 2018b).

\section{Bridge $\mathrm{I}-03-\mathrm{A}$}

Bridge I-03-A was configured with two Airmar EchoRange $^{\mathrm{TM}}$ Smart ${ }^{\mathrm{TM}}$ Sensor echosounders (Airmar Technology Corporation, 2017), each mounted on opposite sides of pier 4 at the transition of the upstream nose to the straight section of the pier wall (fig. 4). The sensors were located to measure streambed elevations on both sides of the upstream nose of the pier. The east and west echosounders were mounted at elevations of 4,632.83 and 4,632.55 ft, respectively, above the NAVD 88. Each echosounder has a beam width of 9 degrees, 


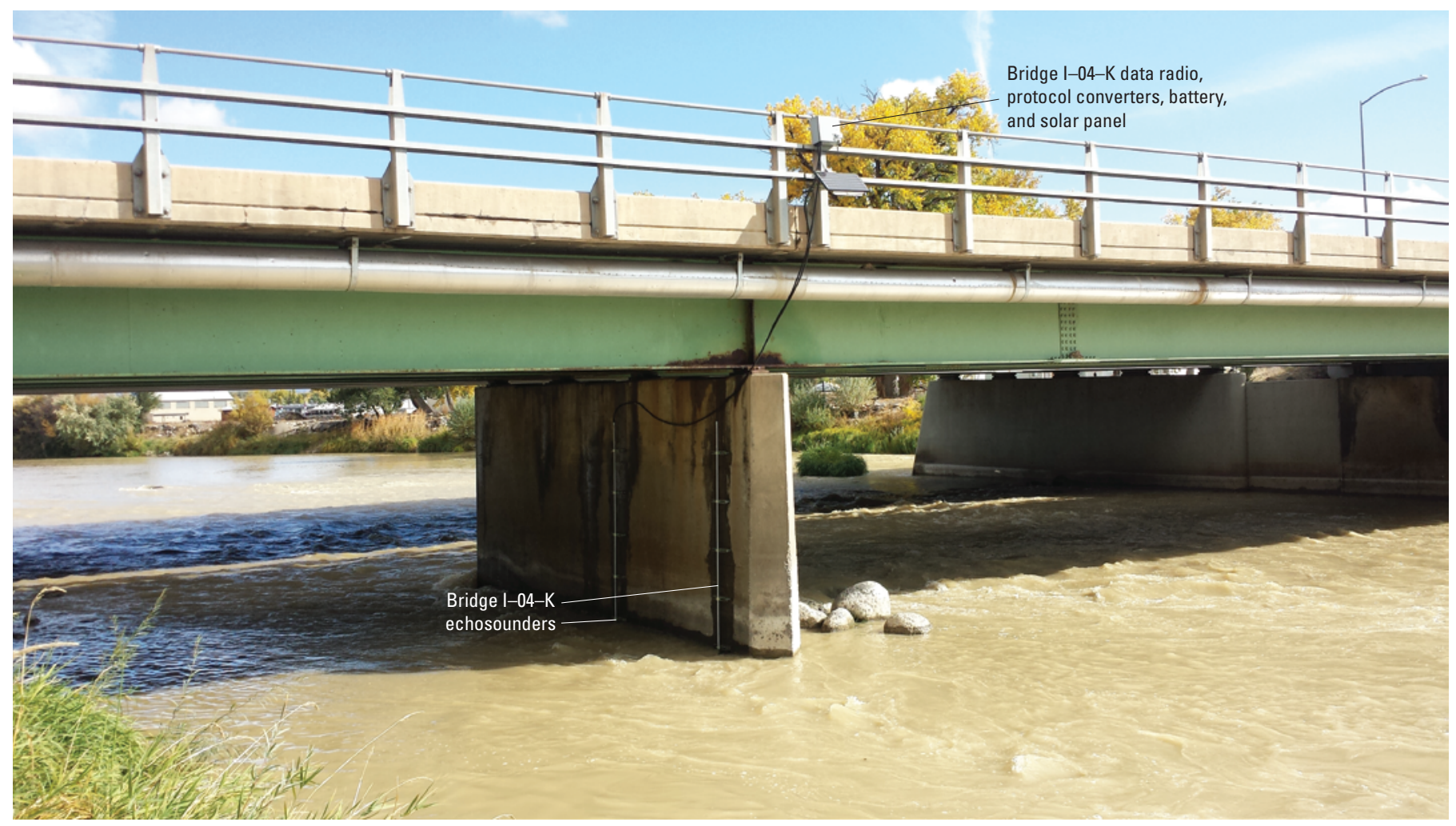

Figure 3. Sensor installation on bridge I-04-K, from the north side of pier 3, looking upstream, western Colorado; photograph by the U.S. Geological Survey.

which resulted in an acoustic footprint of about $1.2 \mathrm{ft}$ in diameter at the base of the pier, assuming the distance to streambed of about $10 \mathrm{ft}$. The diameter of the acoustic footprint changes with measured distance because streambed elevations vary over time.

Each sensor was connected to a protocol converter, which were housed in a small weatherproof enclosure on the bridge railing. The protocol converters were connected to the DCP by a three-conductor cable running across the bridge to the DCP, which was at the right abutment. Right and left are from the perspective of an observer looking downstream. Streambed elevation data were recorded every 15 minutes and transmitted every hour by the DCP. Incoming data were hosted on the NWIS website for USGS streamflow-gaging station 09152500 (USGS, 2018c).

Because of the depth and velocity along the pier, a motorboat was necessary to install all instrumentation on the pier. Inspecting the streambed and pier interface was difficult and accomplished using a 10-foot extended wading rod and underwater camera.

In addition to the echosounders, a side-looking acoustic Doppler velocimeter was installed on the west side of pier 4 for a separate study to measure water velocity and suspendedsediment concentrations mid-channel. Unfortunately, the instrumentation malfunctioned three times during this study, rendering all data unusable.

\section{Cross-Section Survey Techniques and Statistical Analyses}

Cross-section surveys were completed at each bridge to measure and document changes in channel geometry during the study. Surveys were performed in spring 2016 before snowmelt runoff, spring 2017 before snowmelt runoff, and fall 2017. The surveys thus bracketed the real-time data collection periods. Real-time kinematic Global Navigation Satellite System (RTK-GNSS) methods were used to determine the elevations of CDOT survey monuments at each bridge following methods in Rydlund and Densmore (2012). The monuments were subsequently used as the base for cross-section surveys measured with optical levels and sounding weights following procedures in Kenney (2010) and Turnipseed and Sauer (2010). Because the bridge deck obscured a clear view of the sky, collection of RTK-GNSS survey points was not possible under the bridge. Cross-section survey plots are presented in figures 5 and 6; stationing and elevation data are presented in a USGS data release (Henneberg, 2018).

Streambed elevations from cross-section surveys at both bridges were evaluated using two-tailed, paired t-tests and Wilcoxon rank sum tests (Helsel and Hirsch, 2002) to identify changes in channel geometry between the surveys. Streambed elevations were interpolated at 10 -ft intervals between the measured points for both bridges because 


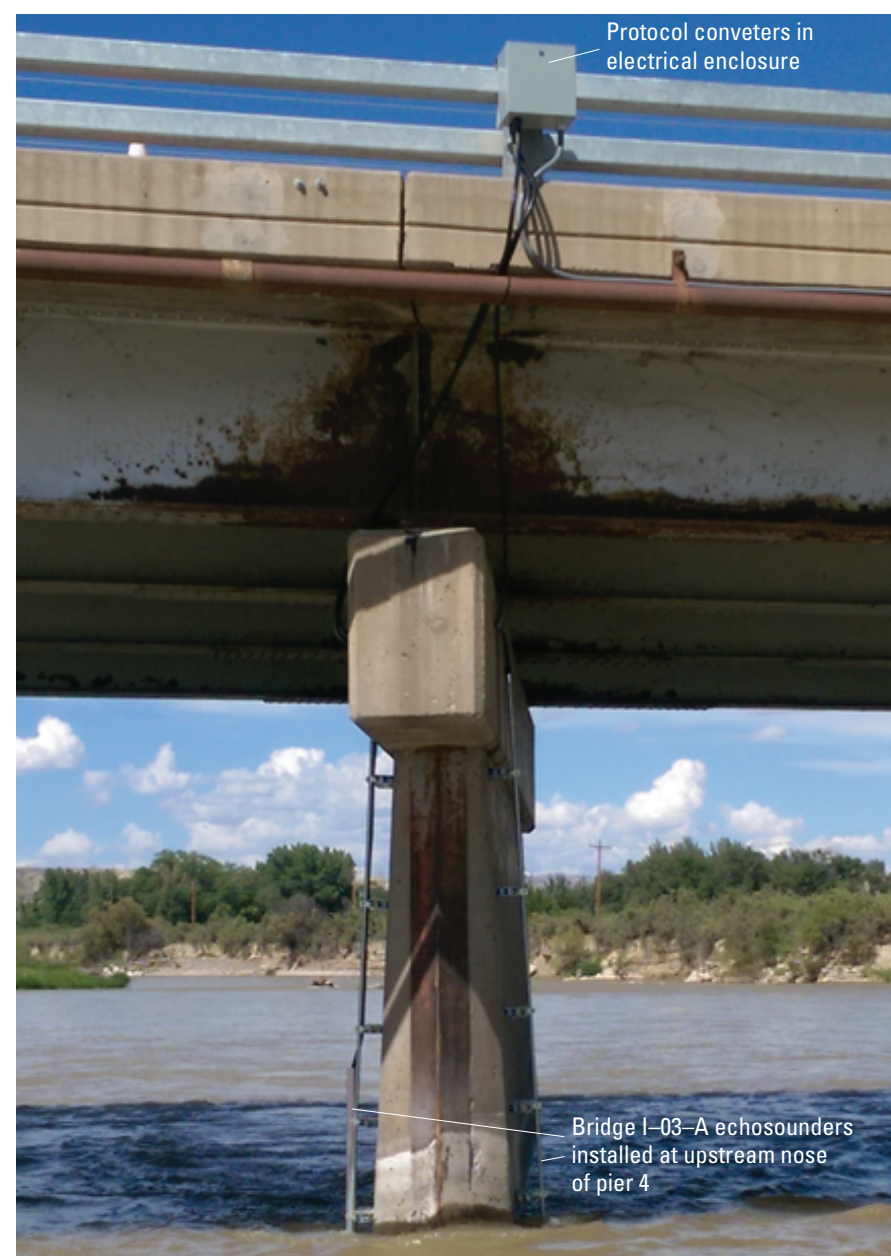

Figure 4. Sensor installation on bridge $\mathrm{I}-03-\mathrm{A}$, from the south side of pier 4, looking downstream, western Colorado; photograph by the U.S. Geological Survey.

measured elevations were not always obtained at the exact same stationing. The starting and ending stations were omitted from the tests because they were immediately adjacent to the bridge abutments. The cross-section surveys were obtained at the bridge openings closest to the echosounders but do not represent the cross sections at the precise echosounder locations.

The statistical tests also were performed on streambed elevations interpolated at 5 - $\mathrm{ft}$ intervals for stations within $20 \mathrm{ft}$ of either side of the monitored piers. These locations are referred to as "pier sections." The pier section tests were intended to identify differences in streambed elevations across the cross section versus localized changes around the piers. All the tests were run on three periods to identify when changes may have occurred: spring 2016 to spring 2017, spring 2016 to fall 2017, and spring 2017 to fall 2017. Results from the statistical tests may provide additional information about streambed processes at the two bridges.

\section{Quality Assurance}

The CDOT monuments were surveyed using RTK-GNSS methods. These data are referenced to Universal Transverse Mercator zone 12 north projection, the North American Datum of 1983, and the NAVD 88 geoid 2012B model. Data were collected with a Trimble R8 GNSS base unit receiver and TDL450H radio and R8 GNSS rover receiver with TSC3 data collector following the techniques and methods in Rydlund and Densmore (2012). The RTK-GNSS position precision, as rated by the manufacturer, is $0.033 \mathrm{ft}$ horizontally and $0.066 \mathrm{ft}$ vertically (Trimble, 2003).

The installed echosounder elevations were determined with optical levels, using the CDOT monuments as the base. Depth measurements at each echosounder were made using an extended wading rod during periodic site inspections to validate the echosounder data.

\section{Real-Time Streambed Scour Monitoring}

In this section, discussions of observed conditions and evaluation of cross-section surveys at bridges $\mathrm{I}-04-\mathrm{K}$ and I-03-A and implications for future monitoring are presented.

\section{Bridge I-04-K}

Bridge I-04-K carries eastbound U.S. Highway 50 traffic over the Gunnison River and is co-located with USGS streamflow-gaging station 09144250 (Gunnison River at Delta, Colo.). It is a 4-span bridge with concrete abutments and piers, which are founded on driven piles. The bridge was built in 1966 (CDOT, 2012b).

The echosounders for this study were mounted on the north side of pier 3 (fig. 5). Field inspections by USGS staff identified local scour along the downstream one-half of the pier wall on the north side. The echosounders were located to measure streambed elevations within the scour hole, at the upstream and downstream extents. The scour hole also exhibited undermining of the pier wall, about $1 \mathrm{ft}$ deep and extending $1 \mathrm{ft}$ under the pier wall. Water depths adjacent to the pier wall ranged from 3 to $4 \mathrm{ft}$ during lower streamflow with the greatest depths at the downstream end of the pier. Estimated water velocity was about 2.5 to 3.5 feet per second (ft/s), based on direct observation.

The echosounders and all associated telemetry instrumentation were installed in September 2015 in advance of the 2016 snowmelt-runoff season. A cross-section survey and site inspection were performed in spring 2016 to verify proper sensor operation before runoff.

As data collection began before snowmelt-runoff, erratic and erroneous values were recorded from the echosounders during the first rising streamflow in April. Field inspections, diagnostics, and discussions with the echosounder 


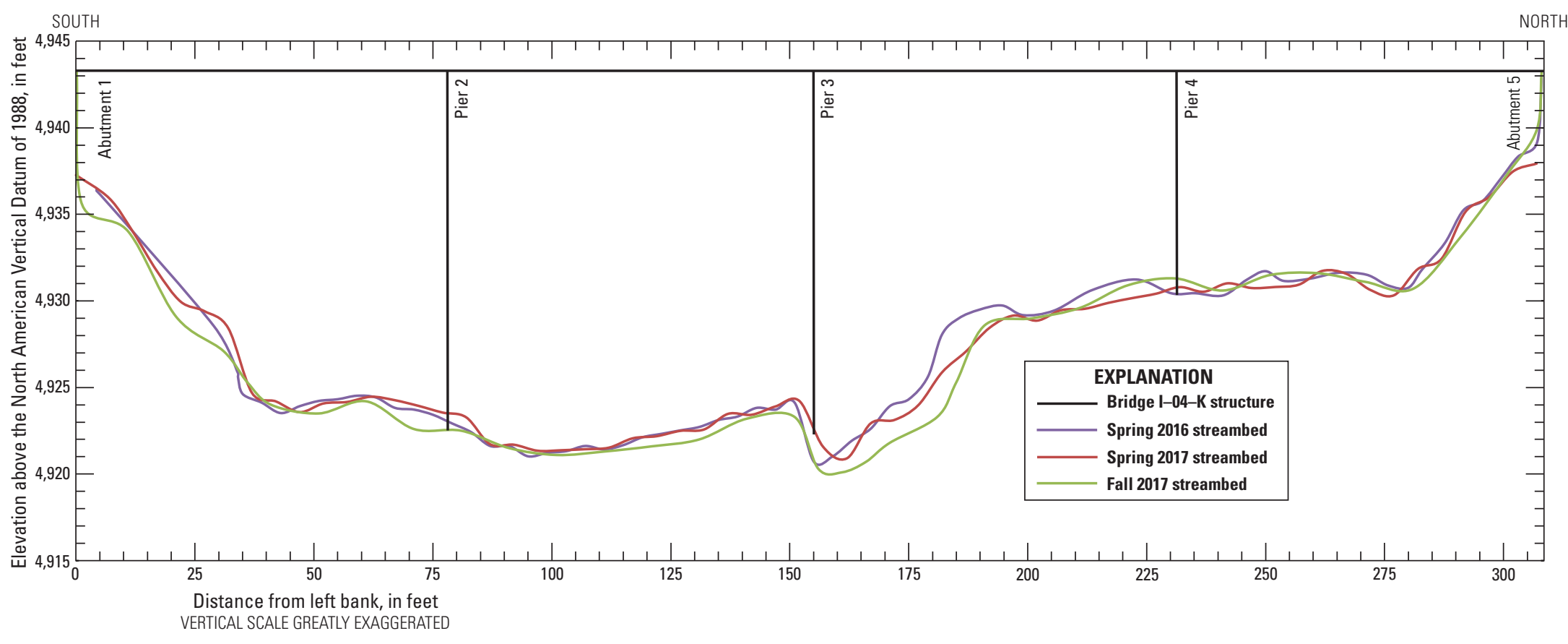

Figure 5. Cross section of streambed elevation surveys of the Gunnison River at bridge I-04-K with the location of the bridge structure, western Colorado, 2016 and 2017. 


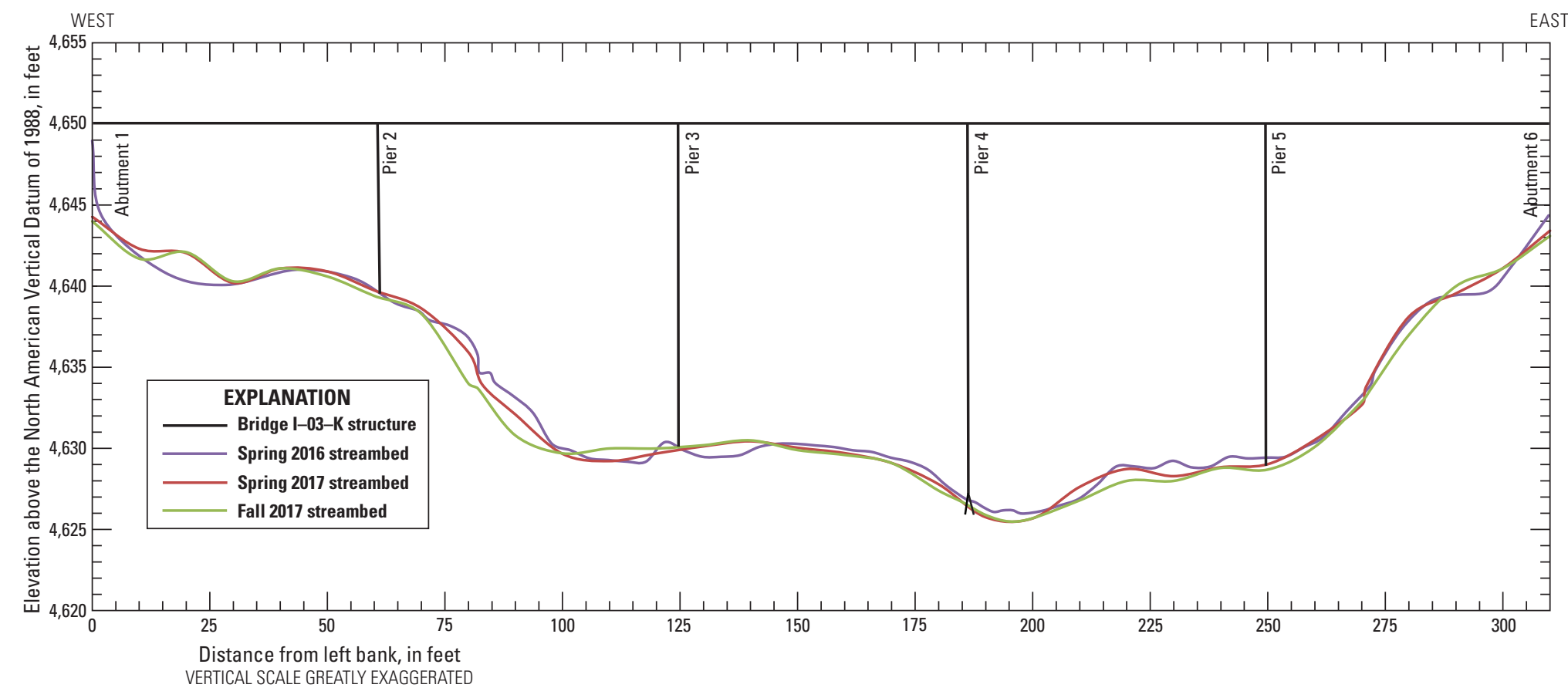

$\infty$

Figure 6. Cross section of streambed elevation surveys of the Gunnison River at bridge I-03-A with the location of the bridge structure, western Colorado, 2016 and 2017. 
manufacturer indicated that the two sensors were interfering with each other. This was not an issue until streamflow and suspended-sediment concentrations increased slightly during the first rising streamflow of snowmelt runoff in April. During low streamflow conditions with clear water, the two echosounders functioned properly. The upstream echosounder was disconnected, but it was not removed. It remained in place for the duration of the study for use as a backup sensor if needed. Once isolated, the downstream echosounder functioned properly for the rest of the study period.

The snowmelt-runoff period of 2016 had a maximum peak streamflow of 9,170 cubic feet per second $\left(\mathrm{ft}^{3} / \mathrm{s}\right)$ on May 22 and a highest daily mean streamflow of $8,560 \mathrm{ft}^{3} / \mathrm{s}$ also on May 22 at USGS streamflow-gaging station 09144250. This peak streamflow ranks 15 of 42 published peaks and is greater than the average peak streamflow of $8,010 \mathrm{ft}^{3} / \mathrm{s}$ and the median peak streamflow of $6,240 \mathrm{ft}^{3} / \mathrm{s}$ from 1976 through 2017 (USGS, 2018b).

Data collected during 2016 snowmelt runoff did not indicate substantial scour under the downstream sensor. The measured streambed elevation was about $4,921.5 \mathrm{ft}$ for the duration of the runoff period (USGS, 2018b).

The snowmelt-runoff period of 2017 had a maximum peak streamflow of 14,900 $\mathrm{ft}^{3} / \mathrm{s}$ on May 25 and a highest daily mean streamflow of $14,400 \mathrm{ft}^{3} / \mathrm{s}$ on May 26 at USGS streamflow-gaging station 09144250 . This peak streamflow ranks 4 of 42 published peaks and is above the average peak streamflow of $8,000 \mathrm{ft}^{3} / \mathrm{s}$ and the median peak streamflow of 6,240 $\mathrm{ft}^{3} / \mathrm{s}$ from 1976 through 2017 (USGS, 2018b).

Data collected during 2017 snowmelt runoff seems to exhibit minor scour and fill under the downstream sensor (fig. 7). The measured streambed elevation was about $4,921.5 \mathrm{ft}$ as streamflow began to increase during May. This elevation remained nearly constant until the streamflow rose above $10,000 \mathrm{ft}^{3} / \mathrm{s}$. Elevations slowly decreased through the streamflow peak to an elevation of 4,921.2 ft during the peak, then rose slightly back to $4,921.5 \mathrm{ft}$ (fig. 7). As runoff progressed, the elevation decreased and subsequently rose on two more occasions during June, both coinciding with the higher-streamflow period of the snowmelt-runoff hydrograph. The first occurrence had a low elevation of 4,921.2 ft, and the second had a low elevation of 4,920.8 ft. As streamflow continued to recede, the measured streambed elevation slowly increased to $4,921.5 \mathrm{ft}$ and remained nearly constant for the duration of the period (fig. 7).

Williams and others (2013) also looked at previous studies and characterized sediment transport conditions at 4 cross sections downstream from bridge I-04-K. They concluded that widespread entrainment, or "significant motion" of the streambed, likely occurs only at streamflows greater than $13,300 \mathrm{ft}^{3} / \mathrm{s}$ in the reach below bridge I-04-K. Streamflow at USGS streamflow-gaging station 09144250 during 2016 did not exceed this threshold. However, daily mean streamflow did exceed 13,300 $\mathrm{ft}^{3} / \mathrm{s}$ on 3 days in 2017 (USGS, 2018b), which correspond with the peak streamflow for the year and the first occurrence of possible scour and fill under the downstream echosounder.

Two-tailed, paired t-tests and Wilcoxon rank sum tests were completed for streambed elevations obtained from cross-section surveys for three periods: spring 2016 to spring 2017, spring 2016 to fall 2017, and spring 2017 to fall 2017. Both tests assumed a null hypothesis of no change in mean streambed elevations between periods and a significance level ( $p$-value) of 5 percent (0.05). At bridge I-04-K, the cross section and the pier section had $p$-values greater than 0.05 for the first period, indicating no significant change to mean streambed elevations from spring 2016 through spring 2017 (table 1). For spring 2016 through fall 2017, which includes both highstreamflow seasons, the $p$-values for both sections were less than 0.05 , indicating a significant change to mean streambed elevations throughout the 2-year study period (table 1 ). The $p$-values for spring 2017 to fall 2017 alone were greater than 0.05 for the cross section but less than 0.05 for the pier section (table 1). This indicates that mean streambed elevations close to the pier changed primarily during this period. This finding is consistent with echosounder readings and the graphical representation of the surveyed cross section (fig. 5); however, the cross section changed gradually during the study, and not because of either year's streamflow conditions alone.

All mean streambed elevations decreased during periods with $p$-values less than 0.05 , indicating section-wide degradation and localized scour processes had occurred when changes in mean streambed elevations were statistically significant (table 1). The mean streambed elevation for the cross section decreased by $0.39 \mathrm{ft}$, whereas mean streambed elevations for the pier section decreased by 0.81 and $0.86 \mathrm{ft}$ for the statistically significant periods. The median sediment-particle size (d50) of the streambed sediment, determined for a previous study, was 79 millimeters $(\mathrm{mm} ; 0.26 \mathrm{ft}$; Williams and others, 2013). Deducting the $\mathrm{d} 50(0.26 \mathrm{ft})$ from the 0.81 and $0.86 \mathrm{ft}$ decrease indicated around the pier, a decrease in mean streambed elevations of 0.55 to $0.60 \mathrm{ft}$ approximates the $0.70 \mathrm{ft}$ streambed elevation change measured by the downstream echosounder. The d50 values were deducted from changes in streambed elevation to reduce noise that could result from sediment transport without degradation. The magnitude of the detected scour is about 2-3 particle diameters in extent and, as such, may represent limited movement of the streambed. It is important to note that the surveyed cross sections were at the downstream bridge opening, about $5 \mathrm{ft}$ downstream from the echosounder, so direct comparisons of elevations from the cross sections versus the echosounder would not be appropriate. Indications of significance from the paired t-tests and Wilcoxon rank sum tests support changes between surveys illustrated in the graphical representation of surveyed crosssection data presented in figure 5 . 


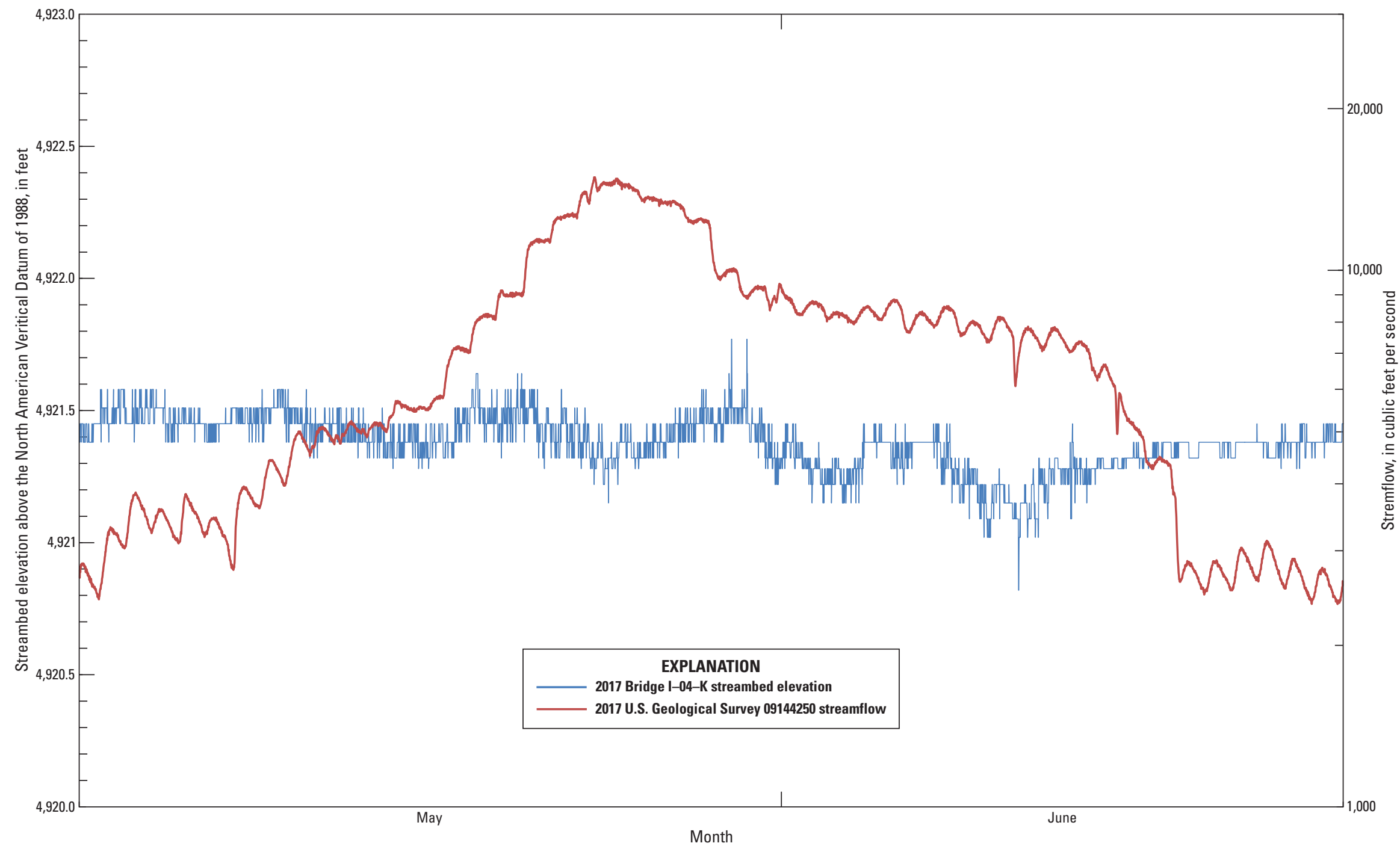

Figure 7. Streambed elevation at bridge I-04-K and streamflow from U.S. Geological Survey streamflow-gaging station 09144250 during snowmelt runoff in 2017, western Colorado. 
Table 1. Streambed-elevation data and statistical test results of comparisons of survey data at bridge I-04-K, western Colorado, 2016-17.

[Grouping of data for statistical tests are indicated by color shading of rows; $p$-value, significance level; --, not applicable.]

\begin{tabular}{|c|c|c|c|c|c|}
\hline Period & $\begin{array}{l}\text { Mean streambed } \\
\text { elevation, } \\
\text { in feet }\end{array}$ & $\begin{array}{c}\text { Sample } \\
\text { variance, } \\
\text { in feet }\end{array}$ & Observations & $\begin{array}{c}\text { Two-tailed, } \\
\text { paired t-test } \\
p \text {-value }\end{array}$ & $\begin{array}{c}\text { Wilcoxon } \\
\text { rank sum } \\
p \text {-value }\end{array}$ \\
\hline \multicolumn{6}{|c|}{ Cross section } \\
\hline Spring 2016 & $4,927.28$ & 21.34 & 30 & 0.117 & 0.245 \\
\hline Spring 2017 & $4,927.12$ & 20.46 & 30 & -- & -- \\
\hline Spring 2016 & $4,927.28$ & 21.34 & 30 & 0.011 & 0.007 \\
\hline Fall 2017 & $4,926.89$ & 22.89 & 30 & -- & -- \\
\hline Spring 2017 & $4,927.12$ & 20.46 & 30 & 0.060 & 0.085 \\
\hline Fall 2017 & $4,926.89$ & 22.89 & 30 & -- & -- \\
\hline \multicolumn{6}{|c|}{ Pier section } \\
\hline Spring 2016 & $4,922.95$ & 1.59 & 9 & 0.844 & 0.314 \\
\hline Spring 2017 & $4,923.00$ & 0.82 & 9 & -- & -- \\
\hline Spring 2016 & $4,922.95$ & 1.59 & 9 & 0.012 & 0.012 \\
\hline Fall 2017 & $4,922.14$ & 1.45 & 9 & -- & -- \\
\hline Spring 2017 & $4,923.00$ & 0.82 & 9 & 0.001 & 0.004 \\
\hline Fall 2017 & $4,922.14$ & 1.45 & 9 & -- & -- \\
\hline
\end{tabular}

\section{Bridge I-03-A}

Bridge I-03-A carries Colorado Highway 141 traffic over the Gunnison River and is co-located with USGS streamflowgaging station 09152500 (Gunnison River near Grand Junction, Colo.). It is a 5 -span bridge with concrete abutments and piers, which are founded on driven piles. The bridge was built in 1958 (CDOT, 2012a).

The echosounders were mounted on pier 4 , which is mid-channel in the deepest section of the river, and would be most likely to experience scour during high streamflow. Water depths adjacent to the pier vary from about 8 to $10 \mathrm{ft}$ during low streamflow, and the greatest depths are at the upstream nose. Estimated water velocity along the pier wall ranged from 2 to $3 \mathrm{ft} / \mathrm{s}$ during low streamflow, based on direct observation. Velocity was marginally higher on the east side of the pier wall because of misalignment to flow direction.

The echosounders and all associated instrumentation were installed in September 2015 in advance of the 2016 snowmelt-runoff season. A cross-section survey and site inspection were performed in spring 2016 to verify proper sensor operation before runoff. Probing of the pier wall and streambed interface from a boat revealed undermining along the length of the pier wall. The undermining extended from side-to-side to a depth of about $2 \mathrm{ft}$. Underwater photographs were obtained by submerging a waterproof camera on an extended wading rod to document the location and extent (fig. 8). Undermining along the entire length of the pier suggests reach-length channel degradation, as opposed to localized scour. Minor to moderate debris was noted at the upstream nose of the pier during this inspection.

The snowmelt-runoff period of $2016 \mathrm{had}$ a maximum peak streamflow of $10,500 \mathrm{ft}^{3} / \mathrm{s}$ on May 22 and a highest daily mean streamflow of $9,920 \mathrm{ft}^{3} / \mathrm{s}$ on May 17 at USGS streamflow-gaging station 09152500 . This peak streamflow ranked 61 of 109 published peaks and was less than the average peak streamflow of $12,800 \mathrm{ft}^{3} / \mathrm{s}$ and the median peak streamflow of 11,500 ft³ $/ \mathrm{s}$ from 1897 through 2017 (USGS, 2018c).

Data recorded during 2016 did not indicate substantial scour under either echosounder. Elevation time-series data from the echosounders remained steady when tracking the streambed through 2016; the east sensor streambed elevation was about 4,624 ft, and the west side streambed elevation was about 4,626 ft (USGS, 2018c). Debris accumulation around the nose of the pier and under the echosounders presented a recurring problem and resulted in erratic data. Debris would not only accumulate on the nose of the pier, but also would sink to the streambed and become entangled between the undermined front of the pier and the piles supporting the pier wall.

The snowmelt-runoff period of 2017 had a maximum peak streamflow of $16,300 \mathrm{ft}^{3} / \mathrm{s}$ on May 26 and a highest daily mean streamflow of $15,900 \mathrm{ft}^{3} / \mathrm{s}$, also on May 26, at USGS streamflow-gaging station 09152500 . This peak streamflow ranks 31 of 109 published peaks and is greater than the average peak streamflow of $12,800 \mathrm{ft}^{3} / \mathrm{s}$ and the median peak streamflow of 11,500 ft³ from 1897 through 2017 (USGS, 2018c). 


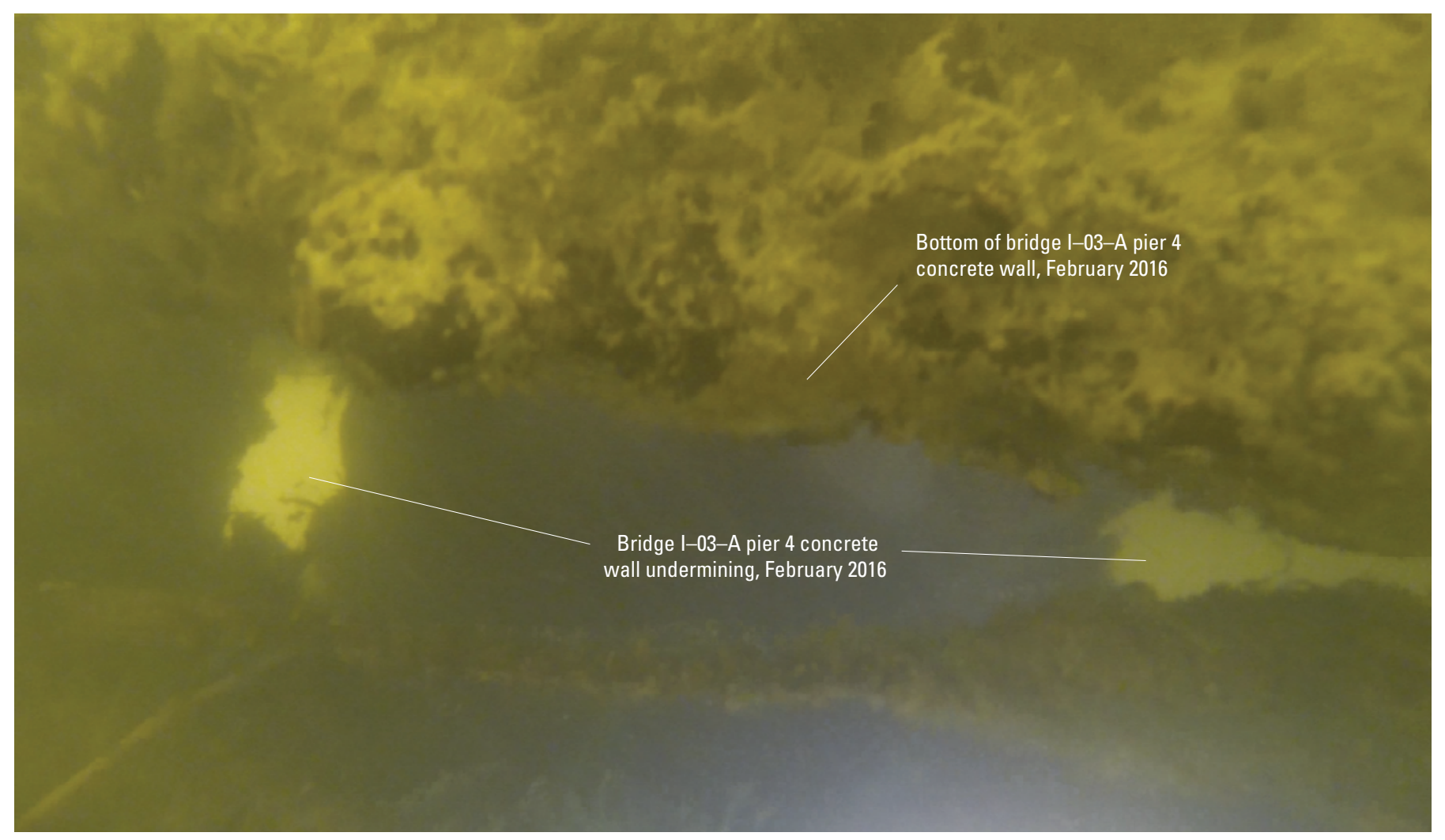

Figure 8. Underwater photograph of undermining of bridge I-03-A at pier 4, western Colorado, February 2016; photograph by the U.S. Geological Survey.

Data recorded during 2017 did not indicate substantial scour under either echosounder. Elevation time-series data were like those recorded in 2016; the east sensor recorded elevations of about $4,624 \mathrm{ft}$, and the west sensor recorded elevations of about 4,626 ft (USGS, 2018c). As streamflow increased in late April, the east streambed elevation trace gained about $1 \mathrm{ft}$ in elevation under the echosounder. The west echosounder measured elevations between 4,625 and 4,626 ft, with occasional debris resulting in unreasonable and erratic elevations. The echosounders measured similarly through the high-streamflow period and as streamflows receded (USGS, 2018c). On June 3, the west echosounder installation was damaged by debris. The east echosounder continued to function, but the data were affected by debris for the remainder of the deployment. A visit on August 30 to deactivate the site provided confirmation of the debris along the east side of the pier, and photographs obtained during this visit verified underwater conditions like those observed in 2016. No additional undermining was observed.

Previous studies characterized sediment transport conditions at four cross sections immediately upstream from bridge I-03-A, providing estimates of the streamflow needed to initiate motion of the streambed (Williams and others, 2013; Pitlick and others, 1999). A comparison between streambed particle size and streamflow in those studies indicated that parts of the streambed in this reach could be mobile at streamflows of $7,700 \mathrm{ft}^{3} / \mathrm{s}$ or greater. Widespread entrainment or "significant motion" of the streambed likely occurs only at streamflow greater than $14,000 \mathrm{ft}^{3} / \mathrm{s}$ (Williams and others, 2013). No daily mean streamflow at USGS streamflow-gaging station 09152500 in 2016 exceeded 14,000 ft $\mathrm{ft}^{3} / \mathrm{s}$, and daily mean streamflow exceeded $7,700 \mathrm{ft}^{3} / \mathrm{s}$ on 12 days (USGS, 2018c). Daily mean streamflow in 2017 exceeded 7,700 ft $\mathrm{ft}^{3} / \mathrm{s}$ on 25 days, and 4 of those days exceeded the $14,000 \mathrm{ft}^{3} / \mathrm{s}$ threshold (USGS, 2018c).

Two-tailed, paired t-tests and Wilcoxon rank sum tests were completed for streambed elevations obtained from cross-section surveys for three periods: spring 2016 to spring 2017, spring 2016 to fall 2017, and spring 2017 to fall 2017. Both tests assumed a null hypothesis of no change in mean streambed elevations between time periods and a significance level ( $p$-value) of 5 percent (0.05). At bridge I-03-A, the cross section and the pier section reported $p$-values less than 0.05 for the first period, indicating mean streambed elevations changed significantly from spring 2016 through spring 2017 (table 2). For spring 2016 through fall 2017, both sections returned $p$-values less than 0.05 , indicating a significant change occurred during the study (table 2). From spring 2017 to fall 2017, $p$-values were greater than 0.05 for the sections, indicating no significant change to mean streambed elevations from either section during the second year of the study when it was evaluated independently. This suggests that changes to 
Table 2. Streambed-elevation data and statistical test results of comparisons of survey data at bridge I-03-A, western Colorado, 2016-17.

[Grouping of data for statistical tests are indicated by color shading of rows; $p$-value, significance level; --, not applicable.]

\begin{tabular}{|c|c|c|c|c|c|}
\hline Period & $\begin{array}{l}\text { Mean streambed } \\
\text { elevation, } \\
\text { in feet }\end{array}$ & $\begin{array}{c}\text { Sample } \\
\text { variance, } \\
\text { in feet }\end{array}$ & Observations & $\begin{array}{l}\text { Two-tailed, } \\
\text { paired t-test } \\
p \text {-value }\end{array}$ & $\begin{array}{c}\text { Wilcoxon } \\
\text { rank sum } \\
p \text {-value }\end{array}$ \\
\hline \multicolumn{6}{|c|}{ Cross section } \\
\hline Spring 2016 & $4,633.18$ & 28.10 & 30 & 0.029 & 0.009 \\
\hline Spring 2017 & $4,632.94$ & 30.79 & 30 & -- & -- \\
\hline Spring 2016 & $4,633.18$ & 28.10 & 30 & 0.043 & 0.046 \\
\hline Fall 2017 & $4,632.83$ & 30.62 & 30 & -- & -- \\
\hline Spring 2017 & $4,632.94$ & 30.79 & 30 & 0.302 & 0.543 \\
\hline Fall 2017 & $4,632.83$ & 30.62 & 30 & -- & -- \\
\hline \multicolumn{6}{|c|}{ Pier section } \\
\hline Spring 2016 & $4,627.61$ & 2.30 & 9 & 0.001 & 0.008 \\
\hline Spring 2017 & $4,627.05$ & 2.17 & 9 & -- & -- \\
\hline Spring 2016 & $4,627.61$ & 2.30 & 9 & 0.000 & 0.004 \\
\hline Fall 2017 & $4,627.05$ & 2.07 & 9 & -- & -- \\
\hline Spring 2017 & $4,627.05$ & 2.17 & 9 & 0.938 & 1 \\
\hline Fall 2017 & $4,627.05$ & 2.07 & 9 & -- & -- \\
\hline
\end{tabular}

mean streambed elevations occurred primarily during the first year of the study at this site (fig. 6).

Changes in mean streambed elevations indicated by the statistical tests for the pier section and the cross section ranged from 0.11 to $0.56 \mathrm{ft}$. The median sediment-particle size $(\mathrm{d} 50)$ of the streambed sediment, determined for a previous study, ranged from 71 to $77 \mathrm{~mm}(0.23$ to $0.25 \mathrm{ft})$ with a mean of $74 \mathrm{~mm}(0.24 \mathrm{ft}$; Williams and others, 2013). Mean streambed elevations decreased for all statistically significant periods, which may suggest streambed scour or reach-wide channel degradation. Deducting the d50 $(0.24 \mathrm{ft})$ from the 0.56 - $\mathrm{ft}$ maximum change in mean streambed elevations indicated by the statistical tests results in scour at the pier section of $0.32 \mathrm{ft}$ during the first year of the study. The d50 values were deducted from changes in streambed elevation to reduce noise that could result from sediment transport without degradation. The magnitude of the detected scour is about 1-2 particle diameters in extent and, as such, may represent limited movement of the streambed. It is important to note again that the surveyed cross sections were at the upstream bridge opening about $10 \mathrm{ft}$ upstream from the echosounders, so direct comparisons of elevations from the cross sections versus the echosounders would not be appropriate. Indications of significance from the paired t-tests and Wilcoxon rank sum tests support changes between surveys illustrated in the graphical representation of surveyed crosssection data presented in figure 6 .

\section{Advancement of Monitoring Technology and Implications for Future Monitoring}

Because of the real-time nature of this study, it is prudent to offer a brief discussion of the technology used and the possible implications for future monitoring. The protocol adapters developed for this study allow the echosounders to measure, $\log$, and telemeter data at any location with an SDI-12-compliant DCP. This includes DCPs installed at most USGS streamflow-gaging stations nationwide. The adapters simplify installation and do not require custom programming. Industry standard SDI-12 commands are used to measure and retrieve data.

The technology demonstrated at bridge I-04-K can be operationalized using SDI-12 data radios at large multispan bridges over wide rivers, increasing the potential application of this technology nationwide. Echosounders installed on multiple piers, each with a radio link, could communicate with a central DCP used to log and telemeter the data. Wiring length limitations of the echosounders native serial data and SDI-12 data can be eliminated by using radios. Similarly, sites with existing streamflow-gaging stations could be retrofitted with echosounders and radio links. Functionality of the protocol adapters has been expanded since the original development for this study and now includes the ability to parse additional NMEA 0183 data sentences. This allows many different types of NMEA 0183 sensors to be connected to any SDI-12 DCP. 


\section{Summary}

The Colorado Department of Transportation maintains roadways crossing over large streams and rivers where sediment transport and channel alignment changes can affect the structural stability of bridges. Structural stability during and immediately after peak streamflow can be assessed by measuring streambed scour; however, placing personnel or boats in the water during high-streamflow events using traditional methods can be difficult, hazardous, and time consuming.

The U.S. Geological Survey, in cooperation with Colorado Department of Transportation, installed monitoring instrumentation at two bridges in western Colorado to measure streambed elevations in real-time during snowmelt-runoff periods (May through June) in 2016 and 2017. The selected bridges carry U.S. Highway 50 eastbound traffic over the Gunnison River at milepost 70.0 (bridge I-04-K) and Colorado Highway 141 over the Gunnison River at milepost 153.7 (bridge I-03-A).

Cross-section surveys also were completed at each bridge to measure and document changes in channel geometry during the study. Surveys were performed in spring 2016 before snowmelt runoff, spring 2017 before snowmelt runoff, and fall 2017.

Sensors and data collection platforms used at most U.S. Geological Survey streamflow-gaging stations communicate using the Serial Digital Interface at 1,200-Baud (SDI-12) protocol, developed specifically for hydrologic instrumentation. To interface acoustic echosounders, which communicate using the National Marine Electronics Association 0183 protocol, with data collection platforms in widespread use, a protocol converter was developed for the study. The protocol converter receives the serial data sentence from the echosounder, parses the sentence for the pertinent data values, stores these values in a register, and makes the registered values available via the SDI-12 protocol.

Bridge I-04-K was outfitted with two echosounders, each mounted on the north side of pier 3. Field observations identified a scour hole along the downstream north side of the pier, so the sensors were mounted to measure streambed elevations where scour had previously occurred. As data collection began, erratic and erroneous values were recorded from the echosounders. The upstream echosounder was disconnected, and once isolated, the downstream echosounder functioned properly for the rest of the study period. Data collected during 2016 snowmelt runoff did not indicate scour under the downstream sensor. Data collected during 2017 snowmelt runoff indicated minor scour and fill under the downstream echosounder. Streambed elevations from the cross-section surveys were analyzed for changes using two-tailed, paired t-tests and Wilcoxon rank sum tests. The statistical tests were applied to streambed elevations across the cross section and to streambed elevations directly around the monitored bridge pier. The tests indicated statistically significant changes to streambed elevations for the cross-section during the study. Both tests also indicated statistically significant changes to the streambed elevations around the monitored pier during the study and during the second year of the study but not during the first.
Bridge I-03-A was outfitted with two echosounders, each mounted on opposite sides of pier 4, at the transition of the upstream nose to the straight section of the pier wall. Data recorded during 2016 did not indicate any scour under the echosounders. Debris accumulation around the nose of the pier and under the echosounders presented a recurring problem and resulted in inconclusive data. Data recorded during 2017 did not indicate any scour. Probing of the pier wall and streambed interface and underwater photographs obtained in 2016 revealed undermining along the length of the pier wall. The undermining extended side-to-side to a depth of about 2 feet. Photographs were obtained again in 2017; no changes were observed. Streambed elevations from the cross-section surveys were analyzed for changes using two-tailed, paired t-tests and Wilcoxon rank sum tests to identify changes between the surveys. The statistical tests were applied to streambed elevations across the cross section and to streambed elevations directly around the monitored bridge pier. The tests indicated statistically significant changes to streambed elevations for the cross section and around the monitored pier during the first year and during the 2-year study but not during the second year alone.

\section{References Cited}

Airmar Technology Corporation, 2017, EchoRange ${ }^{\mathrm{TM}}$ 200 kHz Smart ${ }^{\mathrm{TM}}$ Sensor: Airmar Technology Corporation web page, accessed December 28, 2017, at http:// www.airmartechnology.com/productdescription.html?id=112.

Butch, G.K., 1991, Measurement of bridge scour at selected sites in New York, excluding Long Island: U.S. Geological Survey Water-Resources Investigations Report 91-4083, 17 p., https://pubs.er.usgs.gov/publication/wri914083.

Colorado Department of Transportation [CDOT], 2012a, Drainage report for structure I-03-A state highway 141 over the over the Gunnison River: Colorado Department of Transportation, $83 \mathrm{p}$.

Colorado Department of Transportation [CDOT], 2012b, Drainage report for structure I-04-K US 50 eastbound over the Gunnison River: Colorado Department of Transportation, $113 \mathrm{p}$.

Colorado Department of Transportation [CDOT], 2015, Impact \& continued risk: Colorado Department of Transportation web page, accessed January 8, 2015, at https://www.codot.gov/projects/floodrelatedprojects/ impact-risk.html.

Conaway, J.S., and Brabets, T.P., 2011, Streamflow and streambed scour in 2010 at bridge 339, Copper River, Alaska, in Dumoulin, J.A., and Dusel-Bacon, C., eds., Studies by the U.S. Geological Survey in Alaska, 2010: U.S. Geological Survey Professional Paper 1784-C, 24 p., accessed December 2017 at https://pubs.usgs.gov/pp/1784/c/. 
Conaway, J.S., and Schauer, P.V., 2012, Evaluation of streambed scour at bridges over tidal waterways in Alaska: U.S. Geological Survey Scientific Investigations Report 2012-5245, 38 p., accessed December 2017 at https:// pubs.usgs.gov/sir/2012/5245/.

Elliot, J.G., and Hammack, L.A., 1999, Geomorphic and sedimentologic characteristics of alluvial reaches in the Black Canyon of the Gunnison National Monument, Colorado: U.S. Geological Survey Water-Resources Investigations Report 99-4082, 74 p., accessed January 2018 at https:// pubs.usgs.gov/wri/1999/4082/report.pdf.

Helsel, D.R., and Hirsch, R.M., 2002, Statistical methods in water resources: U.S. Geological Survey Techniques of Water-Resources Investigations, book 4, chap. A3, 522 p.

Henneberg, M.F., 2018, Cross-section geometry at two bridges over the Gunnison River in western Colorado, 2016-17: U.S. Geological Survey data release, https:// doi.org/10.5066/P92EY47R.

Kenney, T.A., 2010, Levels at gaging stations: U.S. Geological Survey Techniques and Methods 3-A19, 60 p. [Also available at https://pubs.usgs.gov/tm/tm3A19/.]

Mueller, D.S., and Wagner, C.R., 2005, Field observations and evaluations of streambed scour at bridges: Federal Highways Administration RD-03-052, 137 p., accessed January 2018 at https://www.fhwa.dot.gov/publications/research/ infrastructure/hydraulics/03052/03052.pdf.

Murillo, J.A., 1987, The scourge of scour: Civil EngineeringAmerican Society of Civil Engineers, v. 57, no. 7, p. 66-69.

National Marine Electronics Association [NMEA], 2017, NMEA 0183 standard: National Marine Electronics Association web page, accessed November 2, 2017, at https://www.nmea.org/ content/nmea_standards/nmea_0183_v_410.asp.

Pacific Data Systems, 2017, NMEA to SDI-12 protocol converter: Pacific Data Systems web page, accessed December 28, 2017, at http://pacdatasys.com.au/our-products/data-loggerstelemetry/other-loggers/serial-to-sdi-12-protocol-converter.

Pitlick, J., Van Steeter, M.M., Cress, R., Barkett, B., and Franseen, M., 1999, Geomorphology and hydrology of the Colorado and Gunnison Rivers and implications for habitats used by endangered fishes-Final report: Grand Junction, Colo., U.S. Fish and Wildlife Service, 64 p. [Also available at https://www.colorado.edu/geography/geomorph/usfws reports/USFWS99.pdf.]

Rydlund, P.H., Jr., and Densmore, B.K., 2012, Methods of practice and guidelines for using survey-grade global navigation satellite systems (GNSS) to establish vertical datum in the United States Geological Survey: U.S. Geological Survey Techniques and Methods, book 11, chap. D1, 102 p. with appendixes. [Also available at https://pubs.usgs.gov/ $\mathrm{tm} / 11 \mathrm{~d} 1 /$.
SDI-12 Support Group, 2018, Serial Digital Interface at 1200 Baud: SDI-12 Support Group website, accessed January 1, 2018, at http://sdi-12.org/index.php.

Trimble, 2003, Trimble ${ }^{\circledR}$ R7/R8 GPS receiver user guide: Trimble, 216 p., accessed January 21, 2018, https://www.ngs.noaa. gov/corbin/class_description/TrimbleR7-R8_UserGuide.pdf.

Turnipseed, D.P., and Sauer, V.B., 2010, Discharge measurements at gaging stations: U.S. Geological Survey Techniques and Methods, book 3, chap. A8, 87 p.

U.S. Geological Survey [USGS], 2018a, USGS water data for the Nation: U.S. Geological Survey National Water Information System database, accessed January 3, 2018, at https://doi.org/10.5066/F7P55KJN.

U.S. Geological Survey [USGS], 2018b, USGS 09144250 Gunnison River at Delta, CO, in USGS water data for the Nation: U.S. Geological Survey National Water Information System database, accessed January 3, 2018, at https:// doi.org/10.5066/F7P55KJN. [Site information directly accessible at https://waterdata.usgs.gov/co/nwis/uv/?site_ no $=09144250$.]

U.S. Geological Survey [USGS], 2018c, USGS 09152500 Gunnison River near Grand Junction, CO, in USGS water data for the Nation: U.S. Geological Survey National Water Information System database, accessed January 3, 2018, at https://doi.org/10.5066/F7P55KJN. [Site information directly accessible at https://waterdata.usgs.gov/co/nwis/ uv/?site_no=09152500.]

Walker, J.F., and Hughes, P.E., 2005, Bridge scour monitoring methods at three sites in Wisconsin: U.S. Geological Survey Open-File Report 2005-1374, 9 p., accessed January 2018 at https://pubs.usgs.gov/of/2005/1374/.

Williams, C.A., Schaffrath, K.R., Elliott, J.G., and Richards, R.J., 2013, Application of sediment characteristics and transport conditions to resource management in selected main-stem reaches of the Upper Colorado River, Colorado and Utah, 1965-2007: U.S. Geological Survey Scientific Investigations Report 2012-5195, 82 p. [Also available at https://pubs.usgs.gov/sir/2012/5195/.]

For more information about this publication, contact

Director, USGS Colorado Water Science Center

Denver Federal Center, MS-415

Building 53

Denver, CO 80225

1-303-236-6901

For additional information visit https://co.water.usgs.gov/

Publishing support provided by the

Denver and Rolla Publishing Service Centers 


\section{$\mathbb{R}$ \\ क्}

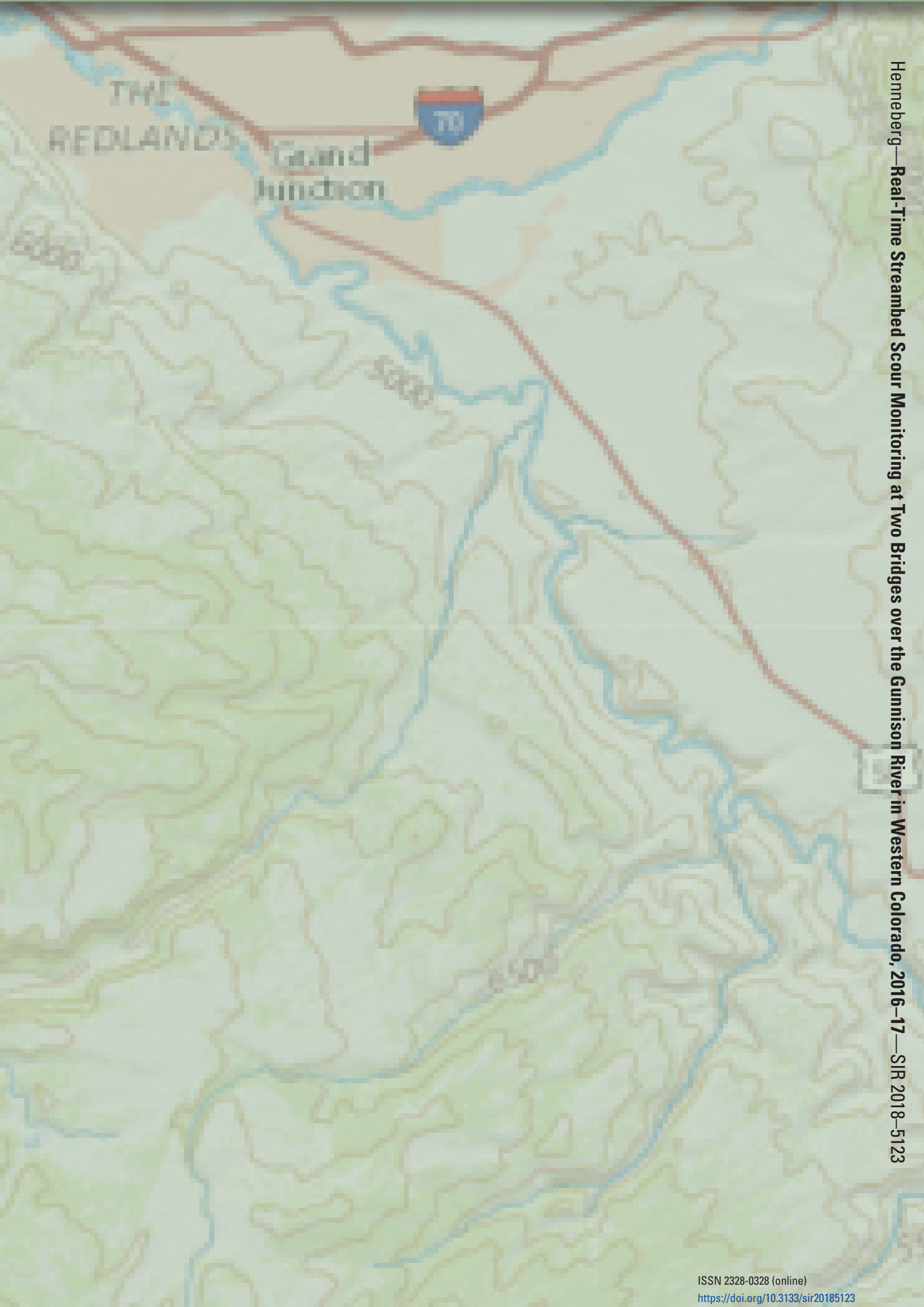

